Studia nad Autorytaryzmem i Totalitaryzmem 41, nr 4 Wrocław 2019

DOI: $10.19195 / 2300-7249.41 .4 .5$

\author{
MATEUSZ NIEĆ
}

ORCID: 0000-0002-0879-682X

Akademia Ignatianum w Krakowie

\title{
Zapomniane zwycięstwo 4 czerwca - o mitologii politycznej filmu Psy Władysława Pasikowskiego
}

Pan niczego nie szuka. Pana nosi pycha, niezdrowa ambicja. Swój los ubiera pan w znaczenie szczególne, ozdabia niepowtarzalnym sensem, upina Pan z niego przejmującą metaforę.

Tadeusz Konwicki, Sennik współczesny

Artykuł podejmuje zagadnienie mitologii, $\mathrm{z}$ dodatkiem politycznej, który to termin nie jest zbytnio rozpowszechniony ani w naukach prawnych, ani $\mathrm{w}$ historii doktryn politycznych, ani w naukach o polityce, ani w myśli politycznej. Zarówno refleksja prawna, jak i nawet refleksja historyków myśli politycznej nie poświęciła zbyt dużo uwagi mitologii ${ }^{1}$. Pojęcie mitologii zostało podjęte przez antropologów kulturowych ${ }^{2}$, religioznawców ${ }^{3}$, filozofów ${ }^{4}$, psychologów $^{5}$,

${ }^{1}$ M. Maciejewski, Mit Hitlera $w$ ruchu narodowych socjalistów $w$ okresie republiki weimarskiej, „Studia nad Faszyzmem i Zbrodniami Hitlerowskimi” 4, 1979, s. 23-41; B. Olszewska-Dyoniziak, Antropologia totalitaryzmu europejskiego XX wieku, Wrocław 1999; T. Biernat, Mit polityczny, Warszawa 1989.

${ }^{2}$ Zagadnienie mitu/mitologii zostało w literaturze antropologicznej i etnograficznej podjęte przez klasyczne już prace J.G. Frazera, E. Durkheima, B. Malinowskiego, M. Maussa, C. Levi-Straussa czy R. Barthes'a. Ze współczesnych rozważań o polskiej mitologii należy wymienić pracę M. Napiórkowskiego, Mitologia współczesna. Relacje o poczynaniach i przygodach krajowców zamieszkatych w globalnej wiosce, Warszawa 2013.

${ }^{3}$ M. Eliade, Sacrum, mit, historia, wstęp M. Czerwiński, przeł. A. Tatarkiewicz, Warszawa 1993; M. Czerwiński, Magia, mit, fikcja, Warszawa 1973; E. Mieletinski, Poetyka mitu, przedmowa M.R. Mayenowa, przeł. J. Dancygier, Warszawa 1981.

${ }^{4}$ E. Cassirer, Mit państwa, przeł. A. Staniewska, Warszawa 2006; idem, Esej o człowieku. Wstęp do filozofii kultury, przedmowa B. Suchodolski, przeł. A. Staniewska, Warszawa 1998.

${ }^{5}$ S. Langer, Nowy sens filozofii. Rozważania o symbolach myśli, obrzędu i sztuki, wstęp H. Buczyńska-Garewicz, przeł. A.H. Bogucka, Warszawa 1976.

Studia nad Autorytaryzmem i Totalitaryzmem 41, nr 4, 2019

(C) for this edition by CNS 
filmoznawców ${ }^{6}$, literaturoznawców ${ }^{7}$ oraz filologów klasycznych ${ }^{8}$. Wśród historyków doktryn politycznych i prawnych, proweniencji zarówno politycznej, jak i prawnej, pojawia się propozycja poszerzenia obszaru badawczego, ale bez bezpośredniego wskazania mitologii. Prawie ćwierć wieku temu Maria Zmierczak i Henryk Olszewski zgłosili propozycję poszerzenia obszaru badań. Wspomniani autorzy z poznańskiego ośrodka naukowego postulowali, aby historyka doktryn interesowały „wielkie klasyczne dzieła wielkich myślicieli, a także dzieła pisarzy religijnych, publicystyka, treści wystąpień przedstawicieli społeczeństwa w organach władzy, literatura piękna, relikty kultury materialnej, symbolika dzieł sztuki"9. Zasadności tych słów nie muszę dowodzić, powstające prace naukowe je udowodniły. Czy jednak w wymiarze wystarczającym, jest już kwestią do dyskusji - w moim przekonaniu zagadnienia te są ciągle niewystarczająco eksponowane w naukach prawnych i politycznych, przy czym w wypadku nauk o polityce badacze związani z refleksją o komunikowaniu podejmują wskazane zagadnienia w dosyć szerokim zakresie, szczególnie badacze związani z paradygmatami szkoły z Toronto lub szkoły z Birmingham.

W artykule prezentuję autorską interpretację Barthes'owskiego ujęcia mitologii, którą określam mianem „mitologia polityczna”. Nie przytaczam jednak koncepcji mitu Rolanda Barthes'a (francuski strukturalista używa obydwu określeń w różnych kontekstach), gdyż doczekała się ona licznych interpretacji ${ }^{10}$, jedynie dla przypomnienia wskazuję najistotniejsze tezy. Koncepcja mitologii politycznej poszerza analizę idei politycznych (ideologii ${ }^{11}$ ) o film i inne formy wizualne (i audialne) oraz literackie, co pozwala na pełniejszą prezentację historii idei ${ }^{12}$.

W ocenie francuskiego strukturalisty mit, podobnie jak język, ,jest systemem porozumiewania się, jest komunikatem”, a zatem „wszystko, co podpada pod wypowiedź, może być mitem. Mitu nie określa przedmiot jego komunikatu,

${ }^{6}$ A. Helman, Co to jest kino?, Kraków 1992; Film: język - rzeczywistość - osoba. Antologia, red. A. Helman, J. Ostaszewski, przeł. M. Hendrykowski, M. Hendrykowska, Warszawa 1992; A. Helman, J. Ostaszewski, Historia myśli filmowej. Podręcznik, Gdańsk 2007.

${ }^{7}$ M. Bachtin, Problemy literatury i estetyki, przeł. W. Grajewski, Warszawa 1982.

${ }^{8}$ Mit, człowiek, literatura, wstęp i red. S. Stabryła, Warszawa 1992.

${ }^{9}$ H. Olszewski, M. Zmierczak, Historia doktryn politycznych i prawych, Poznań 1994, s. 12; Myślenie o polityce i prawie, przedmiot, metoda, praktyka, red. I. Barwicka-Tylek et al., Warszawa 2015.

${ }^{10}$ Właściwie wszystkie prace poświęcone mitologii/mitom podejmują koncepcję Barthes’a; zob. wymienioną literaturę przedmiotu, szczególnie prace Helman, Mieletinskiego i Napiórkowskiego.

11 A. Heywood, Ideologie polityczne. Wprowadzenie, przeł. M. Habura et al., Warszawa 2007.

12 Poza przedmiotem analizy pozostawiam relacje między doktryną polityczną, ideami politycznymi i programem oraz zagadnienie historii idei. 
ale sposób jego wypowiadania: istnieją formalne granice mitu, a nie ma substancjalnych. Wszystko może więc być mitem?"13. Przytoczoną myśl Barthes kończy znakiem zapytania, jak gdyby chciał wskazać przykłady budzące wątpliwość, które następnie wylicza: fotografia, film, reportaż, sport, widowisko, zachowania rytualne, a nawet opalenizna. Barthes analizuje głównie obraz, ikonografię charakterystyczną dla kultury popularnej: „Obraz staje się pismem w momencie, w którym nabiera znaczenia" 14 — staje się językiem, w jakim wypowiada się dana społeczność. Barthes przywołuje więc koncepcję języka Ferdinanda de Saussure'a ${ }^{15}$ oraz koncepcję gramatologii Jacques'a Derridy, który nadał pismu, a właściwie logice pisma, szczególne właściwości znaczące ${ }^{16}$.

Mit jest zbudowany z dwóch systemów semiologicznych: z systemu języka i systemu mitologii; jest wtórnym system semiologicznym. Dlatego zdaniem Barthes'a „mit jest słowem skradzionym i [jednocześnie] oddanym”17. Interpretacja mitycznego przekazu jest aktem samoistnym na poziomie jednostkowego odczytania. Barthes nie rozstrzyga przy tym, czy mit jest komunikatem usytuowanym przez nadawcę w przekazie, jest słowem „skradzionym”, czy mit jest usytuowany u odbiorcy.

Jednostkowe odczytanie przesuwa mitologię z ideologicznej przestrzeni publicznej w prywatne ramy osobowości. Barthes podąża więc drogą wytyczoną przez szkołę frankfurcką stawiającą na pogodzenie analiz filozoficznych z psychoanalitycznym podejściem, przywołuje też propozycję neofreudysty Jacques'a Lacana $^{18}$. Ukazuje przejście od tego, co jednostkowe, do tego, co publicznie, zarazem stawiając pytanie o to, co ideologiczne. Autor Mitologii dokonuje przy tym wyraźnego odróżnienia ideologii od polityki — przypisuje ideologii władzę, w greckim rozumieniu słowa arche, nad tym, co początkowe, inicjujące, natomiast polityka jest dla niego działaniem, realizacją programu, koncepcji.

Zdaniem Barthes'a odbiorca zachowuje się jak krytyk, który najpierw podejmuje działalność strukturalistyczną, odnajduje wewnętrzną strukturę (to, co znaczące na poziomie pierwszego i drugiego odczytania) i następnie odtwarza prawdziwe znaczenie dzieła, ideologiczną wymowę całości (to, co znaczone), odnajduje trzeci sens. Barthes jednoznacznie nie określa przy tym, czy odbiorca odnajduje wpisany w dzieło sens ukryty Autora, czy formułuje własny trzeci sens. Koncepcja śmierci Autora wskazuje na drugie ujęcie, lecz analizy samego Barthes'a dokonane w latach

${ }^{13}$ R. Barthes, Mitologie, wstęp K. Kłosiński, przeł. A. Dziadek, Warszawa 2000, s. 239.

14 Ibidem, s. 241.

15 F. de Saussure, Kurs językoznawstwa ogólnego, wstęp i przypisy K. Polański, przeł. K. Kasprzyk, Warszawa 2002.

16 J. Derrida, O gramatologii, przedmowa, posłowie i przeł. B. Banaszak, Łódź 2011.

17 R. Barthes, op. cit., s. 257.

${ }^{18}$ Francuski strukturalista nawiązuje do Lacanowskiego wyróżnienia realne-wyobrażonesymboliczne. „Rzeczywiste zna tylko różnicę, symboliczne zna tylko maski, jedynie obraz (wyobrażone) jest bliski, jest "prawdziwy «" — R. Barthes, Problem znaczenia w filmie, [w:] Film: język..., s. 20. 
pięćdziesiątych XX wieku w pracy Mitologie byłyby argumentem za pierwszym ujęciem. „Wyjście” poza tekst budzi obawy o dowolność interpretacji.

Zgodnie z założeniami mowy mitycznej każdy przekaz ma dwa układy: pierwszy wynikający z obrazu realnych przedmiotów i zdarzeń, drugi z kontekstów sugerowanych przez nadawcę i z osobistych właściwości odbiorcy (jego doświadczenia, intelektu) oraz uwarunkowań społecznych. Jeśli uwzględnimy obydwa układy w dekodowaniu tekstu, wówczas sens mitu stanie się ,kompletny”, ponieważ mit „zakłada jakąś wiedzę, jakąś przeszłość, jakąś pamięć, jakiś układ odniesienia, złożony z faktów, idei, decyzji”'19. W artykule akcentuję ideologiczne odczytanie, a nie strukturalistyczną interpretację.

Możemy zatem postawić pytanie o kompetencje intelektualne masowego odbiorcy $^{20}$. Barthes niewątpliwie go dowartościowuje. Działalność strukturalistyczna stwarza więc dwa kręgi odbiorców: masy „wyznawców” pozostających w pierwszym odczytaniu i ,wtajemniczonych” potrafiących odnaleźć sens właściwy, przy czym publicznie głoszone interpretacje unieważniają „wtajemniczonych", czyniąc trzeci sens wiedzą powszechną.

\section{II}

W jakim sensie rozumiem frazę „zapomniane zwycięstwo”? Według Waltera J. Onga, jednego z czołowych przedstawicieli szkoły z Toronto, jezuity, termin „interpretacja” „zarówno odsłania, jak i ukrywa" ${ }^{21}$. O tyle jednak odsłonięcie tego, co zakryte, nie wzbudza większych intelektualnych emocji, a nawet powiedziałbym, że oczekujemy odsłonięcia rzeczy zakrytych, o tyle fakt jednoczesnego ukrycia, by posłużyć się słownictwem Onga, wyraźnie nawiązującego do idei mitu Barthes'a, często nam umyka.

W niniejszym tekście przedstawiam wizję Polski po obaleniu komunizmu ${ }^{22}$ pokazaną w obrazie filmowym Władysława Pasikowskiego, która w moim przekonaniu zaważyła na ocenie zwycięstwa 4 czerwca 1989 roku $^{23}$, formułując w prawicowym dyskursie mitologię polityczną pyrrusowego sukcesu, mimo że reżyser dystansował się od politycznych afiliacji. Film Pasikowskiego Psy, który czynię

${ }^{19}$ R. Barthes, Mitologie..., s. 248.

${ }^{20}$ R. Barthes, Problem znaczenia..., s. 18.

${ }^{21}$ W.J. Ong, Tekst jako interpretacja: św. Marek i nieco później, [w:] idem, Osoba, świadomość, komunikacja. Antologia, wstęp, wybór i przeł. J. Japola, Warszawa 2009, s. 176.

22 Podstawą analizy dziejów Polski Ludowej i III RP uczyniłem syntezy: W. Roszkowski, Historia Polski 1914-1991, Warszawa 1992; A. Paczkowski, Pół wieku dziejów Polski 1939-1989, Warszawa 2000; A.L. Sowa, Historia polityczna Polski 1944-1991, Kraków 2011; A. Dudek, Historia polityczna Polski 1989-2012, Kraków 2013; oraz monografię: A. Dudek, Reglamentowana rewolucja. Rozkład dyktatury komunistycznej w Polsce 1988-1990, Kraków 2004. Przedmiotem analizy nie są wydarzenia lat 1989-1991, lecz film Psy, jego mitologiczne przesłanie.

${ }^{23} \mathrm{~W}$ artykule przywołuję republikańską stylistykę. 
przedmiotem analizy, jest obrazem wpisującym się w początek dyskursu określanego w literaturze przedmiotu ideą IV Rzeczypospolitej. Obraz ubeckich początków III Rzeczypospolitej wszedł na stałe do świadomości Polaków — film Pasikowskiego jest bowiem najbardziej kasowym filmem lat dziewięćdziesiątych XX wieku ${ }^{24}$.

W 1992 roku ujawnia się rozczarowanie nową, wolną Polską, by użyć ówczesnego słownictwa politycznego ${ }^{25}$. Słowo „wolność" niesie silniejszy emocjonalny ładunek niż określenie „demokracja” i zostaje w oficjalnym dyskursie publicznym eksponowane w kontekście Frommowskiej Ucieczki od wolności ${ }^{26}$. Rozczarowanie III Rzecząpospolitą jest w mojej ocenie konsekwencją przyjęcia koncepcji terapii szokowej, wyjścia z kryzysu gospodarczego kosztem upadku i likwidacji majątku państwa socjalistycznego ze wszystkimi konsekwencjami społecznymi. Jednocześnie nie pojawiła się realna politycznie alternatywa wobec gospodarczej wizji planu Balcerowicza ${ }^{27}$. Ani ruch związkowy, ani chadecki nie mają wszak wizji przejścia do kapitalizmu, a także programu politycznego budowania demokratycznej Polski. Teoretyczne rozważania ekonomistów, filozofów polityki są interesującymi lekturami na seminarium naukowe, są dyskusją na temat modeli ustrojowych, natomiast nie są programami politycznymi rozwiązującymi konkretne problemy, konflikty.

W początkach III Rzeczypospolitej następuje zawieszenie polityczności, to jest sporu politycznego w demokracji ${ }^{28}$, w myśl hasła „ojczyzna w niebezpieczeństwie”. Cele polityczne transformacji (wyjście z zależności politycznej od wschodniego sąsiada) są w początkowym okresie ważniejsze niż cele ekonomiczne i społeczne (przezwyciężenie kryzysu, podniesienie jakości życia Polaków). „Solidarność", stając na czele ruchu związkowego obalającego komunizm radziecki w Polsce, nie staje się więc beneficjentem zmian politycznych transformacji, a nawet — zdaniem Davida Osta ${ }^{29}$ — doznaje klęski. Ponadto radykalny

${ }^{24}$ https://pl.wikipedia.org/wiki/Psy_(film) (dostęp: 17.12.2018).

25 Pierwsze symptomy rozczarowania pojawiają się późną wiosną 1990 roku, kiedy powstaje „Porozumienie Centrum” głoszące hasła przyśpieszenia przemian politycznych - W. Roszkowski, op. cit., s. 411; T. Torańska, My, Warszawa 2012, s. 3-97.

26 J. Tischner, Etyka solidarności oraz Homo sovieticus, Kraków 2005, s. 141.

27 Symptomatycznym była odmowa objęcia teki wicepremiera i ministra gospodarki przez przewodniczącego stolika gospodarki i polityki społecznej strony solidarnościowej Witolda Trzeciakowskiego. Plan reform gospodarczych opracował minister finansów, a nie gospodarki, co miało zasadniczy wpływ na model zmian ustrojowych. Plan Balcerowicza kontynuował w ogólnych zarysach kierunek reform Mieczysława Wilczka, ministra przemysłu w ostatnim rządzie Polski Ludowej, ale z innych politycznie powodów i formułując ideologicznie inną propozycję gospodarczą L. Balcerowicz, 800 dni, szok kontrolowany, Warszawa 1992; por. A. Dudek, Historia polityczna..., s. 15-99; A.L. Sowa, op. cit., s. 615-624.

${ }^{28}$ Ch. Mouffe, Carl Schmitt i paradoks demokracji liberalnej, [w:] Carl Schmitt. Wyzwanie polityczności, red. Ch. Mouffe, przeł. T. Leśniak, Warszawa 2011.

29 D. Ost, Klęska Solidarności. Gniew i polityka w postkomunistycznej Europie, przeł. H. Jankowska, Warszawa 2007. Książka Osta jest odczytaniem dziejów politycznych Polski w kontekście polityki godności. Bardziej analityczną oceną przedstawiła J. Staniszkis, Postkomunizm. Próba opisu, Gdańsk 2001.

Studia nad Autorytaryzmem i Totalitaryzmem 41, nr 4, 2019

(C) for this edition by CNS 
w formie spór polityczny w obozie solidarnościowym, określany metaforycznie „wojną na górze” (lata 1990-1991), dokonuje dekompozycji obozu władzy i co istotniejsze, podaje $\mathrm{w}$ wątpliwość mit solidarności. Powrót do idei jedności forsowany przez obóz prezydencki od 1991 roku nie udaje się — utrwalają się podziały polityczne.

Na tle realizacji reform politycznych (i gospodarczych) pierwszych lat transformacji dochodzi do wyraźnego przesilenia politycznego w 1992 roku, po raz pierwszy zostaje zakwestionowana polityka obozu solidarnościowego. W samym obozie pojawią się, znajdujące posłuch w szerszej skali, teorie spiskowe: „lewy czerwcowy", postkomunistyczny spisek przy Okrągłym Stole ${ }^{30}$. Wcześniejsze teorie spiskowe (Magdalenka, rewizjoniści/,dzieci dawnego systemu”) są wpisane w koncepcję walki wyborczej ${ }^{31}$, kompromitacji rządu Tadeusza Mazowieckiego i szerzej - elit opowiadających się w 1990 roku za podtrzymaniem kompromisu Okrągłego Stołu ${ }^{32}$. Po przejęciu władzy przez Lecha Wałęsę spory zostają wyciszane, Leszek Balcerowicz - główny architekt reform gospodarczych pozostaje na swoim stanowisku, następuje nawet przyśpieszenie prywatyzacji przedsiębiorstw państwowych, misja tworzenia rządu przez Jana Olszewskiego nie dochodzi do skutku, premierem zostaje Jan Krzysztof Bielecki, podtrzymujący kierunek reform politycznych i ekonomicznych. Ideę dokonanej zmiany dobrze oddaje stwierdzenie ówczesnego prezydenta Lecha Wałęsy: „nowy rząd, stary Sejm czy nowy Sejm i stary rząd", która wskazuje na socjotechniczny zabieg zmiany politycznej w 1990 roku.

30 To wówczas ukazuje się książka W. Bereś, J. Skoczylas, Generał Kiszczak mówi ... prawie wszystko (Warszawa 1991), w której pojawiają się zdjęcia kompromitujące solidarnościową opozycję, stawiające pod znakiem zapytania porozumienia przy Okrągłym Stole i w Magdalence. Była to kolejna udana akcja czarnego PR w polskiej polityce po 1989 roku. Jednocześnie w pracy tej został opublikowany list Czesława Kiszczaka z listopada 1990 roku do ówczesnej opozycji i przedstawicieli Kościoła katolickiego, przestrzegający przed zerwaniem porozumień Okrągłego Stołu (ibidem, s. 279-281). Zarówno zdjęcia, jak i list można było odczytywać jako pewną przestrogę kierowaną w stronę dawnej opozycji demokratycznej przed kwestionowaniem porozumień. Praca K. Dubińskiego, Magdalenka. Transakcja epoki. Notatki z poufnych spotkań Kiszczak-Watęsa (Warszawa 1990) nie rozwiała wątpliwości. Tytuł książki wskazywał raczej na inną treść, niż czytelnik rzeczywiście otrzymał, a jednocześnie w domysłach został rozbudzony, był więc podatny na kolejne sensacje. Jest to klasyczny przykład dominacji strategii PR nad autorskim pomysłem, która dla autora kończy się z reguły niekorzystnie. Praca Dubińskiego leży w lamusie historii zamiast dostarczać dowodów i być podstawą analizy. Udaną polemikę z Kiszczakiem podjął J. Widacki, Czego nie powiedziat generat Kiszczak, Warszawa 1992.

31 T. Torańska, op. cit., s. 3-97.

32 W moim przekonaniu przesadnie krytyczną ocenę rządu T. Mazowieckiego głosi A. Dudek, Historia polityczna ..., s. 47-99. Czas polityczny może być zmienną analizującą, lecz nie jest wartością polityczną. Por. obronę działań rządu Mazowieckiego dokonaną przez L. Balcerowicz, op. cit. W wydanej po dwudziestu latach książce pod zmienionym tytułem L. Balcerowicz, 800 dni. Krótka historia wielkiej zmiany 1989-1991 (Warszawa 2009) autor podtrzymał przytoczone tezy.

Studia nad Autorytaryzmem i Totalitaryzmem 41, nr 4, 2019

(C) for this edition by CNS 
Pasikowski podejmuje zatem diagnozę pierwszych lat transformacji ${ }^{33}$, problem rozczarowania transformacją z perspektywy kulturowej i plebejskiej. Reżyser w wywiadach ocenia Psy jako opowieść o byłej SB. Tego typu wypowiedź odbieram jako zdystansowanie się do prawicowego „Porozumienia Centrum”, do idei IV Rzeczypospolitej. Początkowo film miał nosić tytuł Policjanci z Warszawy ${ }^{34}$.

Konsensus polityczny zostaje zerwany w 1992 roku, niestety przez przywołanie idei ostracyzmu ${ }^{35}$. Opublikowanie listy agentów wywodzących się z opozycji nie mogło być uznane za wiarygodny zabieg, ponieważ zrównywało ofiary i katów. Konflikt wśród elity solidarnościowej przybrał nie tylko ideologiczny i polityczny wymiar, lecz niestety także personalny charakter, rzutujący na poziom i ładunek emocjonalny sporu. Był zakwestionowaniem dorobku 1989 roku, porozumień zawartych przy Okrągłym Stole i Magdalence ${ }^{36}$ oraz polityki ,grubej kreski"37. Paradoksalnie ujawnienie listy agentów nadało polityczne znaczenie teczkom SB — teraz byli funkcjonariusze i politycy kontestujący porozumienie Okrągłego Stołu i Magdalenki mogli swobodnie używać teczek jako instrumentu gry politycznej. Nastąpiła polityzacja teczek SB, która była niedopuszczalna wcześniej, teraz stała się ona normą. W takiej rzeczywistości politycznej powstaje film Pasikowskiego powyżej nakreśliłem kontekst polityczny powstania filmu istotny dla mitologicznej interpretacji oraz dla kształtowania się idei IV Rzeczypospolitej.

\section{III}

Reżyser tak wspomina pracę nad scenariuszem filmu: Juliusz Machulski, który był producentem filmu, ,zażądał ode mnie czegoś aktualnego i osadzonego

33 Termin ,transformacja” jest wyjątkowo nieadekwatny teoretycznie — wskazuje na ciągłość, a nie na zerwanie z dawnym ustrojem, podkreśla aspekt technologiczny zmiany, zaciemnia polityczne cele zmiany.

34 W. Pasikowski, ,,Psy” w kinie, czyli jak się robi filmy, Poznań 1995, s. 22.

35 Idea lustracji przypomina grecką ideę ostracyzmu, osądu politycznego - M. Nieć, O tzw. autorytaryzmie demokracji attyckiej, „Przegląd Prawa i Administracji” 79, 2009, s. 145-171.

36 W Magdalence dopełniono tekst porozumienia nieformalnym uzgodnieniem, gentleman's agreement, mającym początkowo większe znaczenie dla opozycji niż ówczesnej władzy. Klęska obozu władzy spowodowała odwrócenie ról — teraz obóz władzy żądał dotrzymania porozumień. Największymi krytykami podtrzymania porozumień Okrągłego Stołu i Magdalenki było środowisko polityczne skupione wokół „Tygodnika Solidarność” i „Porozumienia Centrum”.

37 „Rząd, który utworzę, nie ponosi odpowiedzialności za hipotekę, którą dziedziczy [...]. Przeszłość odkreślamy grubą linią. Odpowiadać będziemy jedynie za to, co uczyniliśmy, by wydobyć Polskę z obecnego załamania" - T. Mazowiecki, Polska będzie inna. Przemówienie wygłoszone w Sejmie 24 sierpnia 1989 roku, [w:] idem, Rok 1989 i lata nastepne. Teksty wybrane i nowe, Warszawa 2012, s. 41. Mazowiecki nie użył zatem określenia grubej kreski. Określenie ,gruba kreska” jest propagandowym chwytem (wywołanym poprzez skojarzenie „przeszłość odkreślamy grubą linią”) ówczesnych przeciwników politycznych („Porozumienie Centrum”), który w późniejszym czasie stanie się jedną z kluczowych idei IV Rzeczypospolitej. Zob. T. Mazowiecki, Sąd nad grubą kreska, [w:] idem, Rok 1989..., s. 403-424; Z. Domarańczyk, 100 dni Mazowieckiego, Warszawa 1990. 
w rzeczywistości, a ja akurat zastanawiałem się, co się dzieje z dokumentami policyjnymi ${ }^{38} \mathrm{w}$ dobie przełomu ustrojowego. Potem rzeczywiście rozpętała się afera $\mathrm{z} »$ teczkami«"39.

W artykule podejmuję się analizy filmu jako przykładu mitologii politycznej. Wskazuję tylko polityczne konteksty mitologii, wizje artystyczne pozostawiając poza przedmiotem badania. Chciałbym w tym miejscu nadmienić, że wcześniej analizowałem film Władysława Pasikowskiego Pokłosie ${ }^{40}$, tym razem pod lupę biorę film Psy.

Film Pasikowskiego Psy jest jednym z najważniejszych dzieł kinematografii polskiej po 1989 roku; powstał w 1992 roku, był to drugi film autorski (reżyseria i scenariusz) Pasikowskiego - wcześniej nakręcił Krolla, który otrzymał wiele nagród $^{41}$. Psy cieszyły się uznaniem publiczności.

Pasikowski jest $\mathrm{z}$ wykształcenia antropologiem kulturowym ${ }^{42}$, co ma zasadniczy wpływ na jego sposób postrzegania rzeczywistości jako kulturowego portretu środowiska. Interesują go kulturowe aspekty zmiany, postawy bohaterów motywowane przez środowisko, a nie psychologiczne rozterki bohaterów. Stąd wyjątkowa oszczędność w charakterystyce postaci, o czym będzie mowa w dalszej części artykułu.

Reżyser pokazuje świat zbudowany z małych wiosek plemiennych (Praga warszawska, Bałuty łódzkie), ukazuje świat archaiczny i autorytarny rządzący się swoistymi kodeksami i zasadami, świat popeerelowski rozpadający się na naszych oczach pod wpływem kapitalizmu, a właściwie jego podstawowego miernika pieniądza. Na naszych oczach dochodzi do walki między plemionami „dzikich”.

Pasikowski jednoznacznie wpisuje Psy w sytuację polityczną, tak jakby chciał opowiedzieć historię z czasu przełomu, pokazać dokument fabularyzowany (przynajmniej przez pierwsze kilkadziesiąt minut filmu możemy odnosić takie wrażenie). Chce zaprezentować jakieś etnograficzne studium przypadku, przedstawić jedną historię z życia, osadzoną w środowisku zawodowym. Nadaje opowieści realistyczne tło, nie odżegnuje się od polityki, przynajmniej od spraw

38 Oczywiście dokumenty milicji pozostawały wówczas w gestii powstającej policji, dopiero później zostały przekazane do archiwum państwowego.

${ }^{39}$ W. Pasikowski, op. cit., s. 22.

40 M. Nieć, „Pokłosie” W. Pasikowskiego - w poszukiwaniu ofiar Holocaustu. Wokól myśli V.E. Frankla, [w:] Dzieto chwali Mistrza. Ksiega jubileuszowa dedykowana prof. dr hab. Irenie Popiotek z okazji 50-lecia pracy artystycznej oraz pracy pedagogicznej, red. A. Królikowska, M. Łątkowski, B. Topij-Stempińska, Kraków 2016, s. 383-393.

${ }^{41}$ Film Kroll zdobył między innymi Złote Lwy w 1991 roku za scenariusz, najlepszy film, debiut reżyserski oraz nagrodę specjalną jury — https://pl.wikipedia.org/wiki/Kroll (dostęp: 19.12.2018); M. Hendrykowska, Kronika kinematografii polskiej 1895-1997, Poznań 1999, s. 462.

42 Pasikowski studiował w latach 1978-1983 na Uniwersytecie Łódzkim kulturoznawstwo, specjalizacja filmoznawstwo. Razem z nim na roku był Paweł Edelman, autor zdjęć do Krolla i Psów. 
publicznych. Ma pełną świadomość mitologicznego przesłania filmu, jest przecież kulturoznawcą.

Sceną otwarcia filmu Psy jest przesłuchanie przed komisją weryfikacyj$\mathrm{ną}^{43}$, instytucją stricte polityczną, powołaną do życia przez premiera na mocy uchwały Rady Ministrów z 21 maja 1990 roku $^{44}$. Możemy w miarę precyzyjnie wskazać czas opowieści — jesień 1989 i wiosna 1990 roku. Pasikowski zadaje pytanie o kondycję i ideę polskiej demokracji w okresie przebudowy, w okresie anomii. Losy oficerów służby bezpieczeństwa są papierkiem lakmusowym zmiany. Reżyser zamyka film w klamrze komisji weryfikacyjnej — rozpoczyna sceną przesłuchania bohatera filmu Franciszka Mauera ${ }^{45}$, pseudonim Franz ${ }^{46}$, i kończy sceną przesłuchania Franza i wyrzuceniem go z policji, którą dopowiada epilogiem zakończonym w więzieniu ${ }^{47}$. Pomimo skazania Franz okazuje się postacią heroiczną. Film jest pytaniem o kondycję demokratycznego państwa tu i teraz. I jest to odpowiedź optymistyczna. Państwo demokratyczne dosyć szybko i bez większych problemów zbudowało instytucję policji, mimo pewnych trudności

${ }^{43}$ Oficjalna nazwa komisji powołanej do zweryfikowania pracowników byłej Służby Bezpieczeństwa do pracy w policji brzmiała „Centralna Komisja Kwalifikacyjna”. W województwach zostały powołane wojewódzkie komisje kwalifikacyjne (48), które wydawały opinie w pierwszej instancji, natomiast odwołanie od wojewódzkiej komisji rozpatrywała Centralna Komisja. Powołano jeszcze Komisję do spraw Kadr Centralnych. Komisje miały orzekać, czy dany funkcjonariusz ma właściwe kwalifikacje moralne (nie naruszał praw i godności innych osób) i czy w toku służby nie naruszył prawa ( 8 uchwały nr 69 Rady Ministrów z dnia 21 maja 1990 roku). W skład komisji wchodzili: dwaj posłowie i jeden senator z danego województwa, działacze „Solidarności” i komitetów obywatelskich oraz przedstawiciele szefa Urzędu Ochrony Państwa, komendanta wojewódzkiego policji i związków zawodowych.

${ }^{44}$ Uchwała nr 69 Rady Ministrów z dnia 21 maja 1990 roku w sprawie trybu i warunków przyjmowania byłych funkcjonariuszy Służby Bezpieczeństwa do służby w Urzędzie Ochronny Państwa i w innych jednostkach organizacyjnych podległych Ministrowi Spraw Wewnętrznych oraz zatrudniania ich w Ministerstwie Spraw Wewnętrznych, [w:] Historia z konsekwencjami, rozmawiają K. Kozłowski, M. Komar, Warszawa 2009, s. 275-280; A. Dudek, Reglamentowana rewolucja..., s. 451-481; J. Widacki, op. cit., s. 26-29. Zob. też Raport Rokity. Sprawozdanie Sejmowej komisji Nadzwyczajnej do Zbadania Działalności MSW, wstęp J. Rokita, posłowie A. Dudek, Kraków 2005. Procedurze weryfikacji poddało się około 14,5 tysiąca byłych funkcjonariuszy SB, to jest około $60 \%$ składu SB z połowy 1989 roku. Około 8 tysięcy funkcjonariuszy przeszło pozytywną weryfikację w pierwszej instancji, w drugiej - 1800 funkcjonariuszy; w sumie około 10 tysięcy (42\%) byłych pracowników SB przeszło pozytywną weryfikację.

${ }^{45}$ Franciszek Mauer, pseudonim Franz (Bogusław Linda). W nawiasie podano nazwiska aktorów odgrywających daną postać.

${ }^{46}$ Funkcja pseudonimów w filmie nie jest oczywista, pełnią one funkcję łącznika między światem przestępców i policji. Pasikowski niewątpliwie przyjął tezę, sformułowaną w kinie francuskim i amerykańskim, przenikania się obydwu światów, widoczną choćby w $W$ kręgu zła w reżyserii J.P. Melville'a (1970) i Bullitt w reżyserii P. Yatesa (1968) — obydwa filmy były bardzo popularne w Polsce.

47 Scena w więzieniu łączy wątek psychologiczny i antropologiczny narracji Pasikowskiego, zamyka go.

Studia nad Autorytaryzmem i Totalitaryzmem 41, nr 4, 2019

(C) for this edition by CNS 
(postawa $\mathrm{Ola}^{48}$, prawdopodobnie bandytka Siwego ${ }^{49}$, Wencela ${ }^{50}$ ). Nowy ${ }^{51}$ zalicza Franza do swoich: „My p s y musimy się trzymać razem”52 (scena w szpitalu) — nastąpiła asymilacja „starego" aparatu milicji i co istotne, Służby Bezpieczeństwa z nową policją. Zarówno Dziadek ${ }^{53}$, Franz, Olo, jak i kapitan Stopczyk ${ }^{54}$ nie zasilili przy tym szeregów policji, przeszli tylko warunkową weryfikację, na kolejnych etapach odpadli. Weryfikacja pozwoliła na dokonanie czystki kadrowej pod kątem prawnym i moralnym. Funkcjonariusze milicji politycznej otrzymali szansę.

Scena przesłuchania, publicznej prezentacji życiorysu i kariery zawodowej rozpoczyna film - główny bohater staje przed komisją weryfikacyjną, puste krzesła zdają się symbolizować porażkę systemu, nie ma nawet kto się za nim ująć. Oceny dokonuje Historia. Scena na wysypisku (teczek) wyraźnie wskazuje skalę problemu, przed jakim stanęło państwo demokratyczne, które na gruncie obowiązującego porządku prawnego oraz politycznej umowy Okrągłego Stołu, dopowiedzianej w Magdalence, zamierzało rozwiązać problem starego aparatu państwa autorytarnego, jego zbrojnego ramienia. Olo po bójce z Nowym wykrzyczy przy metaforycznym ujadaniu psów ${ }^{55}$ oczekiwania środowiska SB:

Co ty, gnoju, myślisz? Myślisz, że jesteś coś warty, że to jest jakaś gówniana gra o stołki?! Co! To jest walka o życie! Rozumiesz! Ile ty masz lat. Co?! Co ty chcesz zrobić! Co chcesz zrobić?! Zagazować 50 tysięcy agentów i informatorów, tak? O to ci chodzi, gnoju jeden, tak? Jak dorośniesz, to zrozumiesz ${ }^{56}$.

Scena przed komisją weryfikacyjną jest à rebours sceną z lat 1944-1947. Wówczas to żołnierze Armii Krajowej stawali przed komisją ${ }^{57}$. Przez odwołanie

48 Porucznik Olgierd Żwirski, pseudonim Olo (Marek Kondrat).

49 Major Gross, pseudonim Siwy (Janusz Gajos).

${ }^{50}$ Senator Wencel, członek komisji weryfikacyjnej (Zbigniew Zapasiewicz).

${ }^{51}$ Podporucznik Waldemar Morawiec, pseudonim Nowy (Cezary Pazura).

52 Wszystkie cytaty pochodzą z filmu, jeśli nie zaznaczono inaczej. Między scenariuszem a filmem są zauważalne różnice; por. W. Pasikowski, Scenariusz filmu fabularnego p.t. „,Psy”, [w:] idem, ,, Psy” w kinie..., s. 37-149. Za pomoc w odsłuchaniu części dialogów i ballady dziękuję pani Oli Starowicz.

53 Pseudonim Dziadek (Ryszard Fischbach)

${ }^{54}$ Kapitan Tadeusz Stopczyk (Edward Linde-Lubaszenko).

55 Scena odbywa się przy dźwiękach muzyki eksponującej napięcie, w tle słychać ujadanie psów, co podnosi dramatyzm sceny. Ujadanie ,"psów” nadaje wypowiedzi Ola środowiskowe przesłanie.

${ }^{56}$ Między scenariuszem a filmem są dosyć istotne różnice, podaję więc tekst scenariusza: „Co ty, wale jeden, myślisz, że to żarty są. Jakieś pieprzone gry. Gnoju, tu chodzi o ludzkie życie i to nie jedno. Co chcesz z nimi zrobić. Chcesz zagazować pięćdziesiąt pięć tysięcy pracowników służby bezpieczeństwa. Co?! Ile ty masz lat, ty szczeniaku, żeby oceniać. Krzyżowiec pieprzony. Inne czasy były. Rozumiesz to. Inne czasy" — W. Pasikowski, Scenariusz..., s. 64.

${ }_{57}$ M. Turlejska, Te pokolenia żałobami czarne... Skazani na śmierć i ich sędziowie, Warszawa 1990.

Studia nad Autorytaryzmem i Totalitaryzmem 41, nr 4, 2019

(C) for this edition by CNS 
się do historii (poprzez scenografię i artefakty ${ }^{58}$ ) Pasikowski ukazuje siłę państwa demokratycznego, które w przeciwieństwie do komunistycznego reżimu stworzyło realną szansę powrotu, dokonało skutecznej pedagogiki resocjalizacyjnej. Bohaterem filmu staje się Franz, były funkcjonariusz SB.

Kolejne sceny ukazują stopień degrengolady środowiska esbeckiego. Scena w stołówce wywołała najwięcej komentarzy i ataków na reżysera. To ona stała się powodem dosyć ostrej wypowiedzi Bożeny Janickiej w Telewizji Polskiej. Dziennikarka tygodnika „Film” określiła dosyć pogardliwie nurt, do którego zaliczyła $P s y$, kinem bandyckim. Określenie „kino bandyckie” przyjęło się w literaturze filmoznawczej ${ }^{59}$.

W obrazoburczej scenie na stołówce ukazany jest akt profanacji wizerunku ${ }^{60}$ Janka Wiśniewskiego, bohatera Grudnia ' $70^{61}$, jednego z mitologicznych bohaterów „Solidarności” ${ }^{2}$. Grupa pijanych esbeków, naśladując gesty i postawę stoczniowców, wynosi na ramionach zap(b)itego kolegę, śpiewając fragment ballady politycznej Janek Wiśniewski padt ${ }^{63}$, będącej jedną z kultowych pieśni podziemia i „Solidarności”. Scena z zabitym Jankiem Wiśniewskim i balladą w tle jest jedną z ważniejszych scen w filmie Andrzeja Wajdy Człowiek z żelaza ${ }^{64}$, ukazującym mitologię powstania „Solidarności”, porzucenia przez robotników wiary w partię i radziecki socjalizm. W filmie Pasikowskiego scena w stołówce pełni zatem istotną funkcję — pokazuje skalę degrengolady moralnej i demoralizacji

58 Stylizowana na lata czterdzieste XX wieku biała koszula Franza.

${ }^{59}$ Do nurtu kina bandyckiego zalicza się następujące filmy: W. Pasikowski, Kroll, Psy i Psy 2. Ostatnia krew; J. Skalski, Miasto prywatne; J. Żamojda, Młode wilki i Młode wilki 1/2; J. Machulski, Kiler; M. Ślesicki, Sara; M. Dejczar, Bandyta; W. Wójcik, serial Ekstradycja - M. Przylipiak, J. Szyłak, Kino najnowsze, Kraków 1999, s. 178-187. Do tego nurtu możemy zaliczyć także: J. Machulski, Kiler-ów 2-óch; O. Lubaszenko, Chłopaki nie płacza, Poranek kojota, $E=m c^{2}$ oraz Sztos 2.

60 „Profanacja” w rozumieniu prawa odnosi się do znieważania symboli państwowych, jest szczegółowo uregulowana w kodeksie karnym, kodeksie wykroczeń oraz Konstytucji RP. Profanację wizerunku odnoszę do politycznej i kulturowej strony komunikowania.

${ }^{61}$ Ballada o Janku Wiśniewskim powstała w reakcji na śmierć 44 osób, które zginęły na Wybrzeżu w 1970 roku. Autorem tekstu jest Krzysztof Dowgiałło, który nie znał personaliów zabitego chłopca i dlatego nazwał go Jankiem Wiśniewskim; muzykę w 1980 roku skomponował Mieczysław Cholewa. Ballada opisuje śmierć Zbyszka Godlewskiego, słowa „Janek Wiśniewski padł” są refrenem ballady.

62 „Janek Wiśniewski” jest symbolicznym określeniem zabitego robotnika walczącego o wolność i demokrację, podobnie jak „nieznany żołnierz” jest symbolicznym określeniem żołnierzy, którzy oddali życie za ojczyznę.

${ }^{63} \mathrm{~W}$ filmie funkcjonariusze SB śpiewają fragment drugiej i pierwszej zwrotki ballady (w takiej kolejności), dodając wojskową komendę „,ztery!”, która nie pojawia się w oryginalnym tekście ballady. Podaję tekst ballady śpiewanej w filmie: „Na drzwiach ponieśli go Świętojańską/ Naprzeciw glinom, naprzeciw tankom./ Dzielnieśmy stali, celnie rzucali,/ Janek Wiśniewski padł/ Cztery!/ Janek Wiśniewski padł./ Cztery!/ Janek Wiśniewski padł".

64 W Człowieku z żelaza martwy „Janek Wiśniewski” przykryty zakrwawioną flagą narodową jest niesiony na drzwiach przez stoczniowców. 
funkcjonariuszy reżimu komunistycznego, którzy nie cofają się nawet przed profanacją wizerunku pomordowanych przez siebie osób.

W scenie wyniesienia zapitego esbeka została ukazana autoprofanacja SB oto wychodzi Polska Ludowa ze swoją moralną degrengoladą, tak jak zasłużyła, bez chwały i fanfar, spita, butna i chamska. Kapitan Stopczyk jakże celnie puentuje osiągnięcia Polski Ludowej, ale też rozczarowanie Polską Ludową środowisk dawnych służb: „wieczorem puszczamy z dymem całą naszą pieprzoną przeszłość" (scena na stołówce). Oto dni upadku, totalnej demoralizacji. Pasikowski ukazuje koniec Polski Ludowej, dyskutuje ze szkołą polską ${ }^{65}$, z jej mitologią, z najbardziej kultowym filmem szkoły polskiej — Popiołem $i$ diamentem w reżyserii Andrzeja Wajdy. U Wajdy II Rzeczpospolita ponosi klęskę militarną (mitologia powstania warszawskiego) i polityczną (w takiej kolejności), u Pasikowskiego Polska Ludowa upada moralnie, nie znajdując obrońców politycznych. To dwa różne odejścia i dwa różne początki.

Scena na wysypisku jest kultowa, podobnie jak śmierć na wysypisku śmieci Maćka Chełmickiego ${ }^{66} \mathrm{w}$ Popiele i diamencie. Jakże to jednak inna śmierć ubrana w białe szaty i skroplona czerwoną barwą narodową, ukazująca ukrzyżowanie Polski (sceny: otwarcia i zamknięcia filmu z udziałem Maćka Chełmińskiego). Maciek Chełmicki zostaje zabity z radzieckiej pepeszy przez polskich żołnierzy w radzieckich strojach, ginie jak bohater mimo zabójstwa Stefana Szczuki. Ginie przy tym jednak nie na polu chwały, lecz na wysypisku. Wajda dowodzi, dlaczego dalsza walka zbrojna była niemożliwa i dokąd by zaprowadziła, uzasadnia kompromis środowisk akowskich z Polską Ludową. Broni i formułuje mit heroiczny Armii Krajowej, powstania warszawskiego i niepodległej II Rzeczypospolitej. Jednocześnie wskazuje moment podjęcia gry z nową władzą i uzasadnia dlaczego. Słynną scenę poloneza w Popiele i diamencie odczytuję w Bachtinowskiej estetyce tańca pijanego błazna z głupcem. Błazen jest reprezentantem świata nierzeczywistego, a głupiec jest obdarzony brakiem poczucia rzeczywistości.

Scena na wysypisku (osobno omawiam sceny palenia teczek) rozgrywa się między Olem a Nowym. Olo nie przejdzie weryfikacji nie tylko przez bójkę z Nowym, już wcześniej Franz sygnalizuje problemy Ola, również absolwenta prawa. Dla Pasikowskiego SB to nie ZOMO, to dobrze wykształceni studenci dobrych kierunków ${ }^{67}$. Olo studiował w Krakowie, na najbardziej prestiżowym polskim uniwersytecie. Pasikowski nie idzie tu na łatwiznę - Olo wyraża nurt dawnego systemu, któremu po drodze będzie z mafią, z pospolitą bandytką; nie tylko przyłączy się do mafii, ale zacznie nawet budować swoją grupę zbrojną, bez skru-

${ }^{65}$ Historię szkoły polskiej (lata 1955-1962) przedstawił T. Lubelski, Historia kina polskiego 1895-2014, Kraków 2015, s. 190-271; idem, Polska Szkoła Filmowa na tle rodzimego kina, [w:] Kino klasyczne. Historia kina, red. T. Lubelski, I. Sowińska, R. Syska, t. 2, Kraków 2012, s. 935992; M. Hopfinger, Perspektywa moralna ,, szkoty polskiej”, „Kino” 1971, nr 11 (71), s. 12-20.

${ }^{66}$ Maciek Chełmiński (Zbigniew Cybulski).

${ }^{67}$ Por. J. Widacki, op. cit. 
pułów moralnych (romans z Angelą ${ }^{68}$, zdrada Franza). Angela, młoda kurewka z Izby Dziecka, od razu rozpoznała w Olu bratnią duszę: „Fajny jest ten Olo, nie, taki śmieszny" (scena w mieszkaniu Franza). Względy moralne jej nie interesują, chce się zabawić. Ona także nie przejdzie weryfikacji, ale moralnej — wybierze przestępczy świat i sama wybierze więzienie (scena w więzieniu z Franzem).

Olo wyraża „twarde” interesy esbeckiego środowiska, to do niego przyjdzie major Gross z Lublina, tak jak „z Lublina” była Polska Ludowa, instalowana (by użyć dawnego języka) przez towarzyszy obcego pochodzenia (eufemizm na określenie żydowskich i szerzej — radzieckich środowisk). Po zrzuceniu Nowego ze skarpy i bójce ${ }^{69}$ Olo wykrzykuje żądania służb: „Jak dorośniesz, to zrozumiesz, że polityka to nie jest »Dziennik Telewizyjny«. Polityka to jesteśmy my tu, na tym wysypisku śmieci. Albo stąd uda nam się wyjść, albo tu zostaniemy na zawsze. Rozumiesz?!”, następuje wtrącenie Nowego „Oszalałeś!”, po czym Olo kończy tyradę: „Rozumiesz, rozumiesz, kurwo, czy nie rozumiesz” ${ }^{\prime 70}$. Pada strzał. To nie są tylko słowa, to jest już realna groźba, co może się stać i już się staje (sceny morderstw w i przed hotelem).

Kolejna scena, także polityczna w podtekście, opisuje spotkanie Ola z majorem Grossem i „wejście” funkcjonariuszy SB do mafii. W ten sposób dowiadujemy się, że mafia w Polsce ma esbeckie korzenie ${ }^{71}$, chociaż Pasikowski pokaże także świat gangsterki pospolitej (bracia Słabi, kurewki Cielęcinki). Reżyser świetnie portretuje polityczną zmianę poprzez kulturowe artefakty — złoty zegarek Grossa jako atrybut mafii. Dostrzega również nowe kulturowe zachowania, butę i arogancję świata przestępczego stawiającego się na równi z państwem scena w hotelu z udziałem dwóch kurewek (Cielęcinki), które z dnia na dzień stają się uznanymi profesjonalistkami i dumnie kroczą po schodach, nie zwracając uwagi na „nową” policję.

Pasikowski pokazuje całą naiwność i nieprzygotowanie opozycji w starciu z brutalną rzeczywistością. O ile Jerzy Andrzejewski w Popiele i diamencie (książce) dyskutuje z tezą Władysława Gomułki, jakoby władza w 1945 roku leżała na ulicy, należało ją tylko podnieść - pytaniem było tylko, kto podniesie czerwony sztandar: PPR czy PPS? — o tyle Pasikowski dyskutuje z tezą okrągłostołowego dogadania, kontraktu. Te palące się wysypiska teczek należało ugasić.

${ }^{68}$ Angela Wenz z Izby Dziecka, pseudonim Angela (Agnieszka Jaskółka).

${ }^{69}$ Scena duszenia obrazuje ówczesną sytuację polityczną po wyborach czerwcowych, którą można skomentować staropolskim powiedzeniem „trzymał Kozak Tatarzyna, a Tatarzyn za łeb trzyma".

70 W scenariuszu cytowany fragment miał brzmieć: ,Za rok, dwa, jak pożyjesz, to się przekonasz, że polityka to nie jest dziennik telewizyjny i wykłady w szkole oficerów. Polityka to jesteśmy my, tu na wysypisku śmieci. Albo tu zostaniemy, albo się stąd wydostaniemy" — W. Pasikowski, Scenariusz..., s. 64.

${ }^{71}$ Pasikowski rozciąga przytoczoną tezę - według niego nie tylko w Polsce mafia ma korzenie dawnych służb, da się to zauważyć także w Niemczech i ZSRR (łącznicy Stasi, człowiek KGB na lotnisku). 
Mimo całej słabości polskiej demokracji sportretowanej u Pasikowskiego przez postacie Nowego oraz posła i adwokata ${ }^{72}$ udaje się zbrojne ramię Polski Ludowej rozbić i opanować. Nowy jest metaforycznie niezdarny i denerwująco prawy, natomiast poseł i adwokat tylko wygrażają, nadal wiecują, nie mają realnej władzy $^{73}$. Zbrojny związek przestępczy (jakim w opinii opozycji było SB) udaje się unieszkodliwić. Udaje się też część esbeków usunąć z pracy (slangowej „firmy"), znaczną część, by użyć słownictwa Franza, który prawdopodobnie wyraża w filmie poglądy Pasikowskiego lub jest mu najbliższy, „kupić”, to jest zatrudnić, kolejna część dawnego środowiska służb sama odejdzie na emeryturę. Zabójcy Maćka Chełmickiego są na wysypisku śmieci. Historia 1989 roku zatacza koło i drwi, pojawia się w ramie farsy, jak pisał Karl Marks w 18 brumiare'e Ludwika Bonaparte, dopowiadając spostrzeżenie filozofa z Jeny.

I jeszcze sceny palenia teczek ${ }^{74}$, w filmie są dwie. Pierwsza, zaraz na począt$\mathrm{ku}$ - akcja dzieje się w nocy, esbecy jadą na akcję, już nie w mundurach. Scena przypomina czas stanu wojennego. Na wysypisku panuje nastrój zabawy, zadowolenia, przechwalania. Bardziej nastrój zwycięzców niż zwyciężonych. A może to ostatnia „zielona” noc. Z dotychczasowej „pieprzonej przeszłości” (kapitan Stopczyk) nic nie zostaje. Wszystko zaczyna się od nowa, ogień jest tu pokazany jako mitologiczny symbol oczyszczenia, lecz i przejścia do nowego świata. Polska Ludowa nie zostawia żadnych pamiątek, nie ma się czym pochwalić. Epoka ginie na naszych oczach, wykluwa się nowy ład, ze swoją degrengoladą, demoralizacją (prokurator Nawrocki ${ }^{75}$, senator Wencel). Padają znamienne słowa Franza pod adresem Wencla (ostatnie przesłuchanie przed komisją weryfikacyjną): „Rządy się zmieniają, a pan zawsze jest w komisji”. Wszystko zdaje się, kolokwialnie mówiąc, pozamiatane, rewolucja jeszcze się na dobre nie zaczęła, a już się zakończyła. Nowa władza przejmuje stare zwyczaje, jednocześnie odcina się personalnie od „starego” aparatu: „Nazywam się major Bień i mam stopień majora” (scena planowania w MSW przed akcją w hotelu). Równocześnie pojawia się zapowiedź idei terapii szokowej, zburzenia gospodarki socjalistycznej i budowy wszystkiego od nowa. Pasikowski portretuje politykę (,gruba kreska”) na kontrze do gospodarski (terapia szokowa).

72 Poseł Rutecki, członek komisji weryfikacyjnej (Stanisław Orzechowski), oraz adwokat Jaromir, członek komisji weryfikacyjnej (Ryszard Pietruski).

${ }^{73}$ Krzysztof Kozłowski otrzymał nominację na podsekretarza stanu w MSW 7 marca 1990 roku, a 10 maja 1990 roku weszły w życie ustawy policyjne. W jego opinii solidarnościową część Rady Ministrów mógł rozpędzić jeden batalion ZOMO/wojska, dopiero rozwiązanie PZPR tworzy przekonanie o nieuchronności zmian politycznych w Polsce - Historia z konsekwencjami..., s. 249

74 Ówczesny szef MSW generał Kiszczak oficjalnie potwierdził palenie teczek opozycji, uzasadniając swoje działanie dobrem publicznym i dbaniem o dobre imię opozycji - W. Bereś, J. Skoczylas, op. cit., s. 277. Ostatni argument należy traktować jako ostrzeżenie formułowane pod adresem dawnej opozycji.

75 Prokurator Nawrocki (Aleksander Fabisiak). 
Reżyser rozpatruje czas przełomu w swojej ulubionej ramie czarno-białej, przy tym w stylistyce noir - mroczny świat, niczym freudowskie lęki i fobie, wychodzi właśnie nocą, ujawniając swoje najgłębsze pokłady, $i d$. To wówczas rozgrywa się to, co dla wielu jest niewidoczne. To nocą rozgrywa się prawdziwa polityka i prawdziwy świat, który w dzień pokazuje swoje inne, uśmiechnięte lub zatroskane, oblicze. Notabene w Psach akcja nie rozgrywa się za dnia, tylko w nocy, lub na obrzeżach świata (scena morderstwa Słabego, scena w fabryce). Oto polityka, zdaje się głosić Pasikowski, która jest wielką manipulacją ludźmi i rzeczywistością.

$$
* * *
$$

Pasikowski podejmuje zatem mit narodzin III RP, dyskutuje z nim. To nie Okrągły Stół i czerwcowe wybory utorowały drogę do wolności, przynajmniej nie wymienione zagadnienia są przedmiotem analizy filmu, lecz walka polityczna toczona na wysypisku teczek. Walka ostra, brutalna, nieprzebierająca w środkach, nawet ocierająca się o śmierć. Pasikowski tworzy wizję dyskutującą z ideami IV Rzeczypospolitej, a także podejmuje temat szkoły polskiej, rozrachunku z przeszłością, tworzy obraz sugestywny, porównywalny do Popiołu $i$ diamentu, obrazoburczy, podejmujący temat świętości narodowej i niecofający się przed uznaniem racji przeciwnika, odrzucający plewy od ziarna. Pasikowski tworzy wizję silnego państwa demokratycznego, które potrafiło poradzić sobie z „najlepiej zorganizowaną mafią na świecie” (Franz, scena w posiadłości braci Słabych) w sposób cywilizowany i demokratyczny. Z tak zdemoralizowanego środowiska udaje się w ciągu kilkunastu miesięcy zbudować policję demokratycznego państwa, rozwiązać wiele problemów. Oto zapomniane zwycięstwo 4 czerwca, zwycięstwo kartki wyborczej demokracji dokończone na wysypisku teczek.

\section{Bibliografia}

\section{Opracowania}

Bachtin M., Problemy literatury i estetyki, przeł. W. Grajewski, Warszawa 1982.

Barthes R., Mitologie, wstęp K. Kłosiński, przeł. A. Dziadek, Warszawa 2000.

Biernat T., Mit polityczny, Warszawa 1989.

Cassirer E., Esej o człowieku. Wstęp do filozofii kultury, przedmowa B. Suchodolski, przeł. A. Staniewska, Warszawa 1998.

Cassirer E., Mit państwa, przeł. A. Staniewska, Warszawa 2006.

Czerwiński M., Magia, mit, fikcja, Warszawa 1973.

Derrida J., O gramatologii, przedmowa, posłowie i przeł. B. Banaszak, Łódź 2011.

Dudek A., Historia polityczna Polski 1989-2012, Kraków 2013.

Dudek A., Reglamentowana rewolucja. Rozktad dyktatury komunistycznej w Polsce 1988-1990, Kraków 2004. 
Eliade M., Sacrum, mit, historia, wstęp M. Czerwiński, przeł. A. Tatarkiewicz, Warszawa 1993.

Film: język - rzeczywistość - osoba. Antologia, red. A. Helman, J. Ostaszewski, przeł. M. Hendrykowski, M. Hendrykowska, Warszawa 1992.

Helman A., Co to jest kino?, Kraków 1992.

Helman A., Ostaszewski J., Historia myśli filmowej. Podręcznik, Gdańsk 2007.

Hendrykowska M., Kronika kinematografii polskiej 1895-1997, Poznań 1999.

Heywood A., Ideologie polityczne. Wprowadzenie, przeł. M. Habura et al., Warszawa 2007.

Hopfinger M., Perspektywa moralna „, szkoły polskiej”, „Kino” 1971, nr 11 (71).

Langer S., Nowy sens filozofii. Rozważania o symbolach myśli, obrzędu i sztuki, wstęp H. Buczyńska-Garewicz, przeł. A.H. Bogucka, Warszawa 1976.

Lubelski T., Historia kina polskiego 1895-2014, Kraków 2015.

Lubelski T., Polska Szkoła Filmowa na tle rodzimego kina, [w:] Kino klasyczne. Historia kina, red. T. Lubelski, I. Sowińska, R. Syska, t. 2, Kraków 2012.

Maciejewski M., Mit Hitlera w ruchu narodowych socjalistów w okresie republiki weimarskiej, „Studia nad Faszyzmem i Zbrodniami Hitlerowskimi” 4, 1979.

Mieletinski E., Poetyka mitu, przedmowa M.R. Mayenowa, przeł. J. Dancygier, Warszawa 1981.

Mit, czlowiek, literatura, wstęp i red. S. Stabryła, Warszawa 1992.

Mouffe Ch., Carl Schmitt i paradoks demokracji liberalnej, [w:] Carl Schmitt. Wyzwanie polityczności, red. Ch. Mouffe, przeł. T. Leśniak, Warszawa 2011.

Myślenie o polityce i prawie. Przedmiot, metoda, praktyka, red. I. Barwicka-Tylek, A. Czarnecka, M. Jaskólski, J. Malczewski, Warszawa 2015.

Napiórkowski M., Mitologia wspótczesna. Relacje o poczynaniach i przygodach krajowców zamieszkatych w globalnej wiosce, Warszawa 2013.

Nieć M., O tzw. autorytaryzmie demokracji attyckiej, „Przegląd Prawa i Administracji” 79, 2009.

Nieć M., ,,Pokłosie” W. Pasikowskiego - w poszukiwaniu ofiar Holocaustu. Wokół myśli V.E. Frankla, [w:] Dzieło chwali Mistrza. Księga jubileuszowa dedykowana prof. dr hab. Irenie Popiołek z okazji 50-lecia pracy artystycznej oraz pracy pedagogicznej, red. A. Królikowska, M. Łątkowski, B. Topij-Stempińska, Kraków 2016.

Olszewska-Dyoniziak B., Antropologia totalitaryzmu europejskiego XX wieku, Wrocław 1999.

Olszewski H., Zmierczak M., Historia doktryn politycznych i prawych, Poznań 1994.

Ong W.J., Osoba, świadomość, komunikacja. Antologia, wstęp, wybór i przeł. J. Japola, Warszawa 2009.

Ost D., Klęska Solidarności. Gniew i polityka w postkomunistycznej Europie, przeł. H. Jankowska, Warszawa 2007.

Paczkowski A., Pół wieku dziejów Polski 1939-1989, Warszawa 2000.

Przylipiak M., Szyłak J., Kino najnowsze, Kraków 1999.

Roszkowski W., Historia Polski 1914-1991, Warszawa 1992.

Saussure F. de, Kurs językoznawstwa ogólnego, wstęp i przypisy K. Polański, przeł. K. Kasprzyk, Warszawa 2002.

Sowa A.L., Historia polityczna Polski 1944-1991, Kraków 2011.

Staniszkis J., Postkomunizm. Próba opisu, Gdańsk 2001.

Tischner J., Etyka solidarności oraz Homo sovieticus, Kraków 2005.

Turlejska M., Te pokolenia żałobami czarne... Skazani na śmierć i ich sędziowie, Warszawa 1990.

\section{Wspomnienia, relacje}

Balcerowicz L., 800 dni. Krótka historia wielkiej zmiany 1989-1991, Warszawa 2009.

Balcerowicz L., 800 dni. Szok kontrolowany, Warszawa 1992.

Studia nad Autorytaryzmem i Totalitaryzmem 41, nr 4, 2019

(C) for this edition by CNS 
Bereś W., Skoczylas J., Generał Kiszczak mówi... prawie wszystko, Warszawa 1991.

Domarańczyk Z., 100 dni Mazowieckiego, Warszawa 1990.

Dubiński K., Magdalenka. Transakcja epoki. Notatki z poufnych spotkań Kiszczak-Watęsa, Warszawa 1990.

Historia z konsekwencjami, rozmawiają K. Kozłowski, M. Komar, Warszawa 2009.

Mazowiecki T., Rok 1989 i lata następne. Teksty wybrane i nowe, Warszawa 2012.

Pasikowski W., ,Psy” w kinie, czyli jak się robi filmy, Poznań 1995.

Torańska T., My, Warszawa 2012.

Widacki J., Czego nie powiedziat generat Kiszczak, Warszawa 1992.

\section{Dokumenty}

Raport Rokity. Sprawozdanie Sejmowej komisji Nadzwyczajnej do Zbadania Działalności MSW, wstęp J. Rokita, posłowie A. Dudek, Kraków 2005.

Uchwała nr 69 Rady Ministrów z dnia 21.V.1990 r. w sprawie trybu i warunków przyjmowania byłych funkcjonariuszy Służby Bezpieczeństwa do służby w Urzędzie Ochronny Państwa i w innych jednostkach organizacyjnych podległych Ministrowi Spraw Wewnętrznych oraz zatrudniania ich w Ministerstwie Spraw Wewnętrznych, [w:] Historia z konsekwencjami, rozmawiają K. Kozłowski, M. Komar, Warszawa 2009.

\section{Źródła internetowe}

https://pl.wikipedia.org/wiki/Kroll (dostęp: 19.12.2018).

https://pl.wikipedia.org/wiki/Psy_(film) (dostęp: 17.12.2018).

\section{FORGOTTEN VICTORY OF 4 JUNE: ABOUT THE POLITICAL MYTHOLOGY OF THE MOVIE DOGS BY WŁADYSŁAW PASIKOWSKI}

\section{Summary}

The article analyzes the victorious election of Solidarity on 4 June 1989. Władysław Pasikowski, a young Polish director, has shown in the movie Dogs (1992) a metaphor of the 4 June victory, which is analyzed in this article. Other issues from the movie are not presented, neither is the contemporary political situation. Only the contemporary context of the movie is presented. The movie Dogs shows a wide political and cultural background of a political change, probably because Pasikowski is a cultural anthropologist, not only a director. The article consists of three parts. In the first part of the article I present a concept of mythology by Roland Barthes in my own interpretation; I named my interpretation a political mythology. In the second part of the text I explain the phrase "forgotten victory" and discuss the political context "forgetfulness." In the last part of the article I analyze the movie Dogs. Pasikowski presented a story of a police officer and his community (political police) during transformation in Poland. Pasikowski showed in the film the last days of the People's Poland, her moral and political downfall. This film gave rise to many voices and commentaries, both positive and disapproving. The film was recognized by victims fighting about liberty as hurtful. Especially, a scene in a policemen canteen was recognized as derogatory. In a few scenes of the movie Pasikowski described the elite of People's Poland. Pasikowski told a story about the last days of People's Poland in the context of a crime. Since the movie Dogs, Pasikowski has debated with the Polish Film School and at the same time he has carried on with moral issues of the 
Polish Film School. He said and showed where the winners of Maciek Chełmicki, the protagonist of the film Popiół i diament (Ashes and Diamonds) of Andrzej Wajda (director) and Jerzy Andrzejewski (writer), are now. Moreover, Pasikowski has discussed in films with Polish right-wing parties and right-wing journalists about the beginning of the Third Republic of Poland.

Keywords: political mythology, the film Dogs, transformation in Poland, 4 June 1989, Solidarity, People's Poland, Third Republic of Poland.

\section{Mateusz Nieć}

mateusz.niec@z.wroc.pl 